\title{
Nutritional Evaluation of Edible Portulaca oleracia as Plant Food
}

\author{
Ali Aberoumand \\ Received: 10 July 2008 / Accepted: 5 September 2008 /Published online: 25 September 2008 \\ (C) The Author(s) 2008. This article is published with open access at Springerlink.com
}

\begin{abstract}
The proximate composition and mineral constituents of Portulaca oleracia L. leaves and stem were evaluated. The leaves and stem contained ashes-22.66\%, crude protein-23.47\%, crude lipid- $5.26 \%$, crude fibre$8.0 \%$ and carbohydrates $-40.67 \%$. The stem and leaves also have high energy values $[303.9 \mathrm{kcal} / 100 \mathrm{~g}$ dry weight (DW)]. Mineral ranges (mg/100 g DW) were: K (14.71), $\mathrm{Na}$ (7.17), Ca (18.71), Fe (0.48) and Zn (03.02). Comparing the leaves and stem mineral contents with recommended dietary allowances, the results indicated that P. oleracia L. leaves and stem could be a good supplement for some nutrients such as protein, carbohydrates, $\mathrm{Ca}, \mathrm{K}, \mathrm{Zn}$ and $\mathrm{Na}$.
\end{abstract}

Keywords Portulaca oleracia L. · Nutritional Value ·

Nutrients · Iran

\section{Introduction}

In developing nations, numerous types of edible wild plants are exploited as sources of food; hence, they provide an adequate level of nutrition to the inhabitants. Recent studies on agropastoral societies in Africa indicate that these plant resources play a significant role in nutrition, food security and income generation (Edmonds and Chweya 1995).

A. Aberoumand $(\bowtie)$

Natural Resources College,

University of Behbahan,

Behbahan, Khuzestan, Iran

e-mail: Aberoumand38@yahoo.com

A. Aberoumand

No 22, Second Alley of Ab va bargh, Zolfeghari Street,

Behbahan, Khuzestan, Iran
Furthermore, Food and Agricultural Organisation reports that at least one billion people are thought to use wild foods in their diet (Burlingame 2000). In Ghana alone, the leaves of over 300 species of wild plants and fruits are consumed. In Swaziland, wild plants provide a greater share of the diet than domestic cultivars. In India, Malaysia and Thailand, about 150 wild-plant species have been identified as sources of emergency food (Burlingame 2000). Similarly, in South Africa, about 1,400 edible plant species are used (Nesamvuni et al. 2001). In Sahel region of Africa, over 200 wild foods were identified as used by the rural communities (Sena et al. 1998). In most of these reports, it was emphasised that nutritionally, these unconventional plant foods could be comparable to or even sometimes superior to the introduced cultivars (Edmonds and Chweya 1995). It is, therefore, worthwhile to note that the incorporation of edible wild and semi-cultivated plant resources could be beneficial to nutritionally marginal population or to certain vulnerable groups within population, especially in developing countries where poverty and climatic changes are causing havoc to the rural populace. In this context, analyses were carried out to evaluate the nutritional content of Portulaca oleracia L. leaves and stem with the hope that it would be incorporated into the food basket of the country (Vadivel and Janardhanan 2000; Funtua 2004; Ifon and Bassir 1980).

In this work, we considered nutritional values of $P$. oleracia as important food plant with food analytical methods.

\section{Materials and Methods}

Plant Material

Fresh $P$. oleracia L. leaves and stem are used as experimental materials which were collected from farm 
lands in Agricultural Research Central of Dezful, Khuzestan province, Iran, in October 2007. The collected plant material was placed in a polyethylene bag to prevent loss of moisture during transportation to the laboratory. Taxonomic identification of the plant was carried out at the Botany Unit, Ramin Agricultural University, Ahvaz, Iran.

\section{Chemical and Instruments}

1. Chemicals: petroleum ether, $1.25 \% \mathrm{H}_{2} \mathrm{SO}_{4}, 1.25 \%$ $\mathrm{NaOH}$, aliquots, concentrated tetraoxosulphate, digestion tablet (a catalyst), ammonia, $45 \%$ sodium hydroxide solution, $20 \%$ boric acid solution, mixed indicator and nitric/perchloric/sulphuric acid (9:2:1 v/v/v) mixture.

2. Instruments: pestle, mortar, 20-mesh sieve, Soxhlet apparatus, desiccator, oven, volumetric flask, energy dispersive X-ray fluorescence (EDXRF), emission spectrometer and flame photometer.

Preparation of the Plant Material for Chemical Analyses

P. oleracia L. leaves and stem were washed with distilled water and dried at room temperature to remove residual moisture, then placed in paper envelope and oven-dried at $55^{\circ} \mathrm{C}$ for $24 \mathrm{~h}$ (Abuye et al. 2003). The dried leaves were ground into powder using pestle and mortar and sieved through 20-mesh sieve. The leaves and stem powder was used for the nutrients analyses.

\section{Proximate Analysis}

The methods recommended by the Association of Official Analytical Chemists (AOAC) were used to determine ash (\#942.05), crude lipid (\#920.39), crude fibre (\#962.09) and nitrogen content (\#984.13; AOAC 1990).

\section{Determination of Crude Lipid and Crude Fibre Content}

Two grams of dried leaves and stem were weighed in a porous thimble of a Soxhlet apparatus, with its mouth plugged with cotton wool. The thimble was placed in an extraction chamber which was suspended above a preweighed receiving flask containing petroleum ether (bp 40$60{ }^{\circ} \mathrm{C}$ ). The flask was heated on a heating mantle for $8 \mathrm{~h}$ to extract the crude lipid. After the extraction, the thimble was removed from the Soxhlet apparatus and the solvent distilled off. The flask containing the crude lipid was heated in the oven at $100{ }^{\circ} \mathrm{C}$ for $30 \mathrm{~min}$ to evaporate the solvent, then cooled in a desiccator and reweighed. The difference in weight was expressed as percentage crude lipid content. Crude fibre was estimated by acid-base digestion with $1.25 \% \mathrm{H}_{2} \mathrm{SO}_{4}$ (prepared by diluting $7.2 \mathrm{~mL}$ of $94 \%$ conc. acid of specific gravity $1.835 \mathrm{~g} \mathrm{~mL}^{-1} /$ $1,000 \mathrm{~mL}$ distilled water) and $1.25 \% \mathrm{NaOH}(12.5 \mathrm{~g} /$ $1,000 \mathrm{~mL}$ distilled water) solutions. The residue after crude lipid extraction was put into a $600-\mathrm{mL}$ beaker, and $200 \mathrm{~mL}$ of boiling $1.25 \% \mathrm{H}_{2} \mathrm{SO}_{4}$ was added. The contents were boiled for $30 \mathrm{~min}$, cooled, filtered through a filter paper and the residue washed three times with $50 \mathrm{~mL}$ aliquots of boiling water. The washed residue was brought back to the original beaker and further digested by boiling in $200 \mathrm{~mL}$ of $1.25 \% \mathrm{NaOH}$ for $30 \mathrm{~min}$. The digest was filtered to obtain the residue. This was washed three times with $50 \mathrm{~mL}$ aliquots of boiling water and finally with $25 \mathrm{~mL}$ ethanol. The washed residue was dried in an oven at $130{ }^{\circ} \mathrm{C}$ to constant weight and cooled in a desiccator. The residue was scraped into a pre-weighed porcelain crucible, weighed, ashed at $550{ }^{\circ} \mathrm{C}$ for $2 \mathrm{~h}$, cooled in a desiccator and reweighed. Crude fibre content was expressed as percentage loss in weight on ignition.

\section{Determination of Nitrogen Content and Estimation of} Crude Protein

Macro-Kjeldahl method was used to determine the nitrogen content of the leaves and stem. Two grams of dried leaves and stem were digested in a $100-\mathrm{mL}$ Kjeldahl digestion flask by boiling with $10 \mathrm{~mL}$ of concentrated tetraoxosulphate (VI) acid and a Kjeldahl digestion tablet (a catalyst) until the mixture was clear. The digest was filtered into a $100-\mathrm{mL}$ volumetric flask, and the solution made up to $100 \mathrm{~mL}$ with distilled water. Ammonia in the digest was steam-distilled from $10 \mathrm{~mL}$ of the digest to which had been added $20 \mathrm{~mL}$ of $45 \%$ sodium hydroxide solution. The ammonia liberated was collected in $50 \mathrm{~mL}$ of $20 \%$ boric acid solution containing a mixed indicator. Ammonia was estimated by titrating with standard $0.01-\mathrm{mol} \mathrm{L}^{-1} \mathrm{HCl}$ solution. Blank determination was carried out in a similar manner. Crude protein was estimated by multiplying the value obtained for percentage nitrogen content by a factor of 6.25 .

Table 1 Proximate composition of Portulaca oleracia L. leaves and stem

\begin{tabular}{lc}
\hline Parameters & Concentration (\% DW) \\
\hline Ash & 22.66 \\
Crude protein & 23.47 \\
Crude lipid & 5.26 \\
Crude fibre & 8.0 \\
Carbohydrates & 40.67 \\
Calorific value & 303.9 \\
$\quad(\mathrm{kcal} / 100 \mathrm{~g})$ & \\
\hline
\end{tabular}


a Proximate Composition of portulaca Oleracia L. leaves and stem

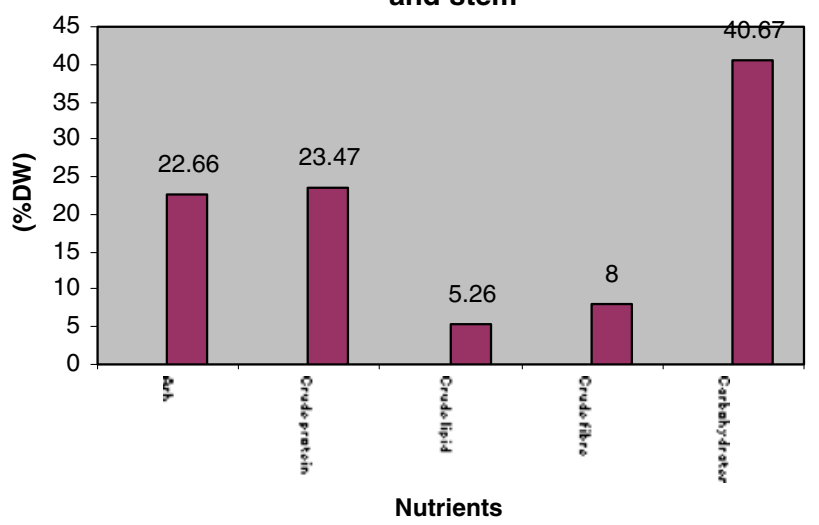

b Minerals composition of Portulaca oleracia L. leaves and stem

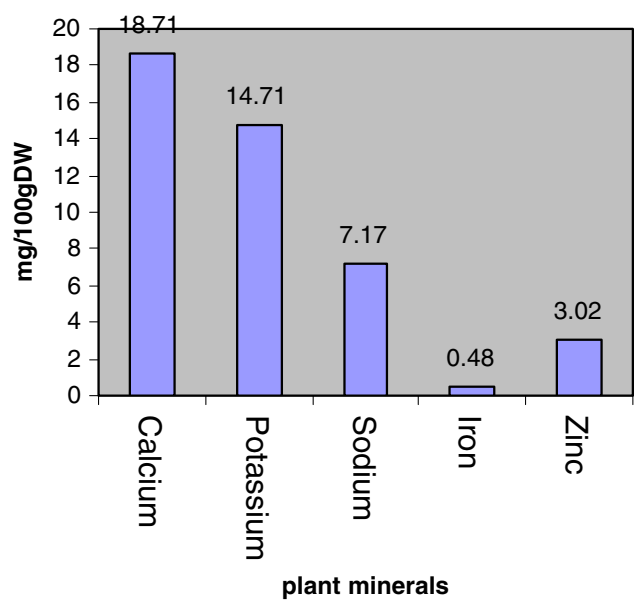

Fig. 1 a Proximate composition of Portulaca oleracia L. leaves and stem b mineral constituents of Portulaca oleracia L. leaves and stem

Estimation of Carbohydrates and Energy Values

Available carbohydrate was estimated by difference, by subtracting the total sum of percent crude protein, crude lipid, crude fibre and ash from $100 \%$ dry weight (DW) of the fruit (AOAC 1990). The fruit calorific value (in $\mathrm{kJ}$ ) was estimated by multiplying the percentages of crude protein, crude lipid and carbohydrate by the factors $16.7,37.7$ and 16.7, respectively (Funtua and Trace 1999).

\section{Mineral Analysis}

The mineral elements $\mathrm{Na}, \mathrm{K}, \mathrm{Ca}, \mathrm{Fe}$ and $\mathrm{Zn}$ were determined on $0.3 \mathrm{~g}$ leaves and stem powder by the methods of Funtua (Lockeett et al. 2000; Hassan and Umar 2006; Pearson 1999) using EDXRF transmission emission spectrometer carrying an annuar $25 \mathrm{mCi} 109 \mathrm{Cd}$ isotopic excitation source that emits Ag-K X-ray $(22.1 \mathrm{keV})$ and Mo X-ray tube $(50 \mathrm{KV}, 5 \mathrm{~mA})$ with thick foil of pure Mo used as target material for absorption correction. The system had a Canberra Si (Li) detector with a resolution of 170 at $5.9 \mathrm{keV}$ line and was coupled to a computercontrolled ADCCard (Trump 8K). Measurements were carried out in duplicate. $\mathrm{Na}$ was analysed after wet digestion of $1 \mathrm{~g}$ of the leafy powder with nitric/perchloric/ sulphuric acid $(9: 2: 1 \quad v / v / v)$ mixture. Sodium was analysed with a Corning 400 flame photometer (AOAC 1990).

\section{Results and Discussion}

The results are shown in Table 1. The ash content, which is an index of mineral contents, for P. oleracia $\mathrm{L}$. leaves and stem, with the value of $22.66 \%$ DW was higher than the values reported for other edible leaves such as $P$. oleracia leaves $(18.00 \pm 1.27 \%$ DW; Faruq et al. 2002; Aletor and Adeogun 1995). It is apparent that P. oleracia L. leaves and stem are a good source of sodium, potassium, calcium and zinc. Protein content (23.47\%) was higher for some lesser known wild leafy vegetables such as $P$. oleracia leaves (11.29 \pm 0.07 ; Sena et al. 1998; AsibeyBerko and Tayie 1999; Aletor and Adeogun 1995; Plessi et al. 1999). According to the Food and Nutrition Board (2001), food plants that provide more than $12 \%$ of their calorific value of protein are a good source of protein. In that context, P. oleracia L. leaves and stem $(23.47 \%)$ are a good source of protein. The crude lipid content $(5.26 \%)$ of

Table 2 Mineral composition of Portulaca oleracia L. leaves and stem

\begin{tabular}{|c|c|c|c|c|c|}
\hline \multirow[t]{2}{*}{ Minerals } & \multirow[t]{2}{*}{ Available quantity in $\mathrm{mg} / 100 \mathrm{~g} \mathrm{DW}$} & \multirow{2}{*}{$\begin{array}{l}\text { Children } \\
7.10 \text { years }\end{array}$} & \multicolumn{3}{|c|}{ Recommended dietary allowances (mg/day) } \\
\hline & & & Adult male & Adult female & Pregnant and breast feeding mothers \\
\hline Calcium & 18.71 & 800 & 800 & 800 & 1,200 \\
\hline Potassium & 14.71 & 1,600 & 2,000 & 2,000 & 2,000 \\
\hline Sodium & 7.17 & 400 & 500 & 400 & 500 \\
\hline Iron & 0.48 & 10 & 10 & 15 & 13 \\
\hline Zinc & 3.02 & 10 & 15 & 12 & 19 \\
\hline
\end{tabular}

At the results of Table 2, there were significant among calcium, potassium, sodium, iron and zinc with $95 \%$ confidence interval $(P<0.05)$ 
the leaves and stem was less than the range $(8.3-27.0 \%$ DW) reported for some vegetables consumed in Nigeria and Republic of Niger (Sena et al. 1998; Isong and Idiong 1997).

Duke and Ayensu (1985) reported amounts of protein (34.5\%), lipid (5.3\%), carbohydrates $(63.2 \%)$ and fibre $(14.6 \%)$ for P. oleracia. Amounts of protein, lipid, carbohydrates and fibre in P. oleracia in our study were compared with the results of the study of Duke and Ayensu, and it is observed that amounts of macronutrients, except lipid, in our study were less than the results of the study of Duke and Ayensu (1985).

The estimated carbohydrate content $(40.67 \%$; Fig. 1) in P. oleracia L. leaves and stem was considered to be higher than that for Senna obtusfolia leaves (20\%) and Amaranthus incurvatus leaves (23.7\%). The crude fibre content in P. oleracia $\mathrm{L}$. leaves and stem $(8.0 \%)$ was comparable to the reported values (8.50-20.90\%) of some Nigerian vegetables (Isong and Idiong 1997). One discussed drawback to the use of vegetables in human nutrition is their high fibre content, which may cause intestinal irritation and a decrease of nutrient bioavailability (Funtua and Trace 1999). The fibre-recommended dietary allowance values for children, adults, pregnant and breast-feeding mothers are $19-25 \%, 21-38 \%, 28 \%$ and $29 \%$, respectively. Thus, the $P$. oleracia $\mathrm{L}$. leaves and stem could be a valuable source of dietary fibre in human nutrition. The calorific value of $P$. oleracia L. leaves and stem was estimated to be $303.9 \mathrm{kcal} /$ $100 \mathrm{~g} \mathrm{DW}$, which is an indication that it could be an important source of dietary calorie. High calorific content of the stem could be attributed to high lipid content.

\section{Mineral Content}

Table 2 shows that the results of the mineral concentrations of P. oleracia L. nutritional significant of iron element is not compared with the standard recommended dietary allowance. When compared with standard values as shown in Table 2, P. oleracia L. leaves and stem are less than adequate level of $\mathrm{K}, \mathrm{Fe}, \mathrm{Zn}, \mathrm{Ca}$ and $\mathrm{Na}$, but the plant fruit could be the good source of $\mathrm{K}, \mathrm{Ca}, \mathrm{Na}$ and $\mathrm{Zn}$. Duke and Ayensu (1985) reported amounts of ash, calcium, iron, potassium and sodium in P. oleracia to be $20 \mathrm{mg} / 100 \mathrm{~g}$, $1,500 \mathrm{mg} / 100 \mathrm{~g}, 29 \mathrm{mg} / 100 \mathrm{~g}, 1,800 \mathrm{mg} / 100 \mathrm{~g}$ and $55 \mathrm{mg} /$ $100 \mathrm{~g}$, respectively. Amounts of ash, calcium, iron, potassium and sodium in P. oleracia in our study were compared with results of Duke and Ayensu; it is observed that amounts of minerals except ash in our study were very less compared with the results of the study of Duke and Ayensu (1985).

\section{Concluding Remarks}

Based on these findings, the $P$. oleracia $\mathrm{L}$. leaves and stem can be recommended as a good source of nutrients (fibre, protein, carbohydrates, $\mathrm{K}, \mathrm{Na}, \mathrm{Ca}, \mathrm{Zn}$ and calorie) to supplement other major sources.

Acknowledgements The authors are grateful to the head of the Department of Botany, University of Pune for providing the necessary laboratory facilities and for the encouragement. The first author is thankful to the head of the Department of Food Science and Technology of Ramin Agricultural University of Iran.

Open Access This article is distributed under the terms of the Creative Commons Attribution Noncommercial License which permits any noncommercial use, distribution, and reproduction in any medium, provided the original author(s) and source are credited.

\section{References}

Abuye C, Urga K, Knapp H, Selmar D, Omwega A, Imungi J et al (2003) East Afr Med J 80:247-252

Aletor V, Adeogun O (1995) Food Chem 53:375-379 doi:10.1016/ 0308-8146(95)99830-S

AOAC (1990) Official methods of analysis, 14th edn. Association of Official Analytical Chemists, Washington DC

Asibey-Berko E, Tayie F (1999) Ghana J Sci 39:91-92

Burlingame B (2000) J Food Compost Anal 13:99-100 doi:10.1006/ jfca. 2000.0897

Duke JA, Ayensu ES (1985) Medicinal plants of China. Reference Publication, Michigan, pp 390-391

Edmonds J, Chweya J (1995) Black nightshades, Solanum nigrum L. and related species. Promoting the conservation and use of underutilized and neglected crops. Bioversity, Rome

Faruq U, Sani A, Hassan L (2002) Nig J Basic Appl Sci 11:157-164

Food and Nutrition Board (2001) Dietary reference intake: elements. Institute of Medicine. National Academy of Sciences, Washington, D.C.

Funtua I (2004) Instrum Sci Technolog 32:529-536 doi:10.1081/CI200029798

Funtua I, Trace J (1999) Plant Foods Hum Nutr 17:293-297

Hassan L, Umar K (2006) Pak J Nutr 5(6):522-529

Ifon E, Bassir O (1980) Food Chem 5:231-235 doi:10.1016/03088146(80)90014-X

Isong E, Idiong U (1997) Plant Foods Hum Nutr 51:79-84 doi:10.1023/A:1007922308985

Lockeett C, Calvert C, Grivetti L (2000) Int J Food Sci Nutr 51:195208 doi:10.1080/09637480050029700

Nesamvuni C, Steyn N, Potgieter M (2001) S Afr J Sci 97:51-54

Pearson D (1999) In: Asibey-Berko E, Tayie F. Ghana J Sci 39:91-92

Plessi M, Bertelli D, Phonzani A, Simonetti M, Neri A, Damiani P (1999) J Food Compost Anal 12:91-96 doi:10.1006/jfca.1999.0812

Sena L, VanderJagt D, Rivera C, Tsin A, Muhammadu I, Mahamadou $O$ et al (1998) Plant Foods Hum Nutr 52:17-30 doi:10.1023/ A: 1008010009170

Vadivel V, Janardhanan K (2000) Plant Foods Hum Nutr 55:369-381 doi:10.1023/A:1008117010991 